Case Report

\title{
Rhinosporidiosis presenting as an orbital mass
}

\author{
Sujan Sharma ${ }^{1}$, Bharat Mani Pokhrel ${ }^{2}$ \\ ${ }^{1}$ Department of Histopathology, National Reference Laboratory, Nepal \\ ${ }^{2}$ Department of Microbiology, National Reference Laboratory, Nepal
}

\section{Keywords: \\ Orbital Mass; \\ Rhinosporidiosis; \\ Sporangium;}

\begin{abstract}
Rhinosporidiosis is a chronic granulomatous disease. Diagnosis is made on the clinical presentation of the patient and confirmed by histopathological findings. We report a case of atypical rhinosporidiosis presenting as orbital mass and mimicked carcinoma. Hence the possibility of rhinosporidiosis should be excluded in the biopsy specimen of the orbital region especially for a patient from rural endemic areas.
\end{abstract}

\author{
Correspondence: \\ Dr. Sujan Sharma, MD \\ Consultant Pathologist, \\ Department of Histopathology, National Reference Laboratory, Nepal, \\ ORCID ID: 0000-0002-8295-2229 \\ Email: sharmasujan2016@gmail.com \\ Reveived : December 14 $4^{\text {st }} 2020$; Accepted : August $17^{\text {th }} 2021$ \\ Citation : Sharma S, Pokhrel BM. Rhinosporidiosis presenting as an orbital mass. J Pathol Nep \\ 2021;12(2):1868-9. DOI: 10.3126/jpn.v11i2.33390 \\ Copyright: This is an open-access article distributed under the terms of the Creative Commons \\ Attribution 4.0 International License, which permits unrestricted use, distribution, and reproduction \\ in any medium, provided the original author and source are credited.
}

\section{INTRODUCTION}

Rhinosporidiosis is a chronic granulomatous disease is caused by Rhinosporidium seeberi and is endemic in a hot tropical climate like India, Sri Lanka, and East Africa. The main reservoirs of infection are water and soil and the mode of transmission is by traumatic inoculation into the tissue where they mature subepithelial and after maturation burst with the release of sporangia into the tissues. ${ }^{1}$ It mainly involves the nasal cavity, nasopharynx, oropharynx, and nasolacrimal duct. However, the involvement of orbits has also been reported. ${ }^{2,3}$

\section{CASE REPORT}




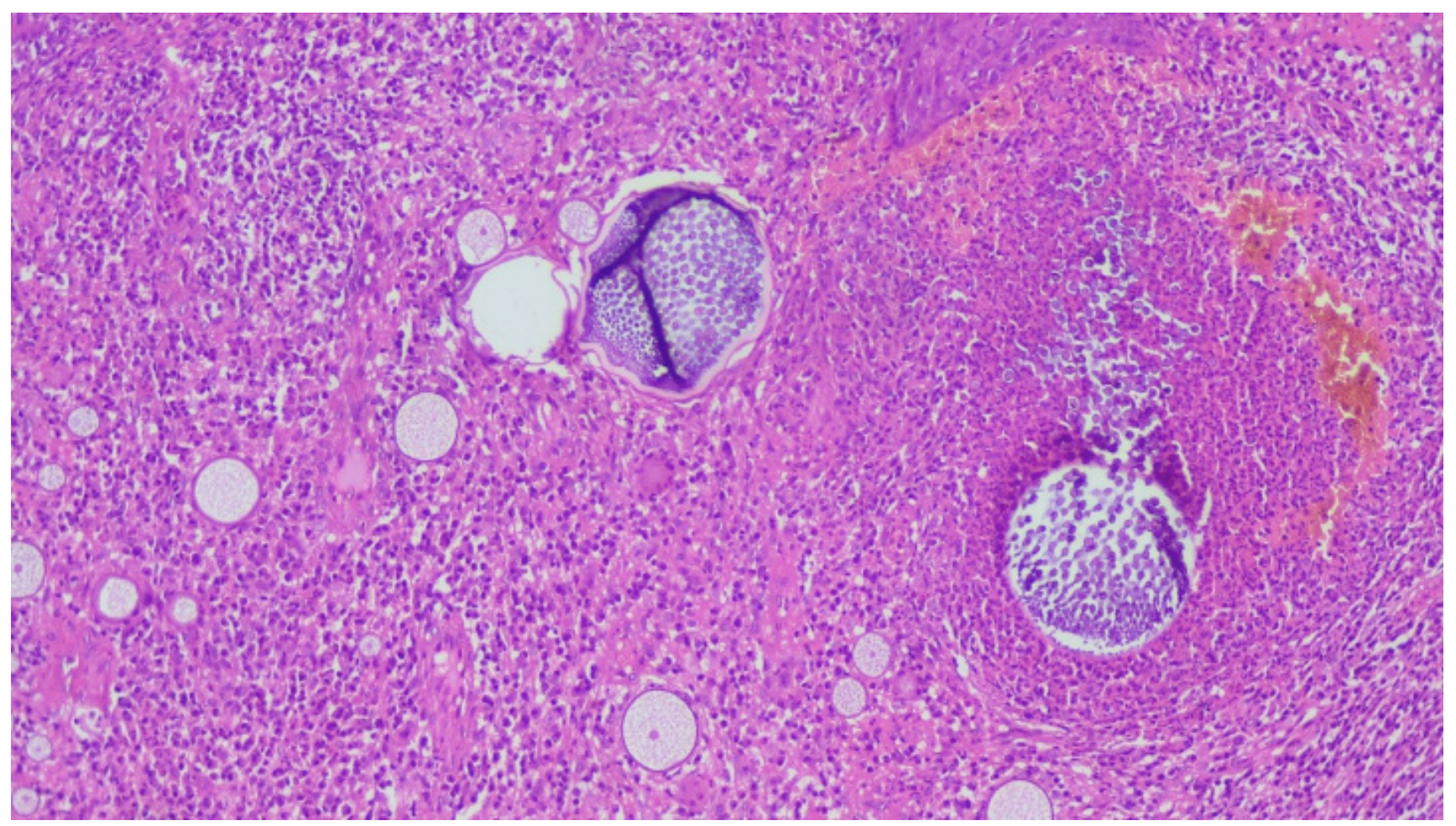

Figure 1: Photomicrograph showing double-walled sporangial cysts with endospores in different developmental stages surrounded by inflammatory cells ( HE stain, X50).

Here we are presenting a case of a 32-year-old male patient from a rural background in the ophthalmology OPD with a chief complaint of blurred vision and pain for a couple of months. Medical history was normal without any systemic symptoms., During the intraocular examination, orbital mass was noticed and an intraocular tumor was suspected. The mass was excised and sent for histopathological examination with clinical differential diagnosis of carcinoma. On histopathological examination fibrocollagenous tissue containing numerous stromal double-walled sporangial cysts with endospores in different developmental stages surrounded by inflammatory cells (fig. 1). The final diagnosis was Rhinosporidiosis.

\section{DISCUSSION}

Rhinosporidiosis is a chronic granulomatous disease caused by Rhinosporidium seeberi. The pathogen enters via traumatic inoculation. The nasal cavity is the most common site, However, few cases presented as bone lesions, and corneal mass had been reported. ${ }^{4}$ They mature subepithelial and release sporangia into the tissue. The diagnosis of RS could be misdiagnosed or delayed when extra nasal sites are involved. The clinical presentation confirmed by histopathological findings is the diagnostic approach. ${ }^{5}$

In our case patient presented with orbital mass and mimicked carcinoma with clinical presentation of blurred vision and pain only. Atypical presentations like ours should be evaluated in a proper manner. The diagnostic approach should be in a careful manner. Because it is a curable disease and failure to diagnose the disease may lead to many problems. ${ }^{6}$

\section{CONCLUSIONS}

This case highlights the unusual presentation of RS clinically. As in this patient, the clinical suspicion of carcinoma. A diagnostic approach in a proper manner could lead to a better prognosis of the patient. Both clinical and histopathological aspects are required to reach the correct diagnosis.

\section{Conflict of Interest: None}

\section{REFERENCES}

1. Von Haacke NP, Mugliston TA. Rhinosporidiosis. J Laryngol Otol. 1982;96:743-50. $\underline{\text { Crossref }}$

2. Neville BW, Damm DD, Allen CM, Bouquot JE. Oral and Maxillofacial Pathology. ${ }^{\text {nd }}$ ed. Philadelphia: Elsevier; 2007. PP928.

3. Nair KK. Clinical trial of diaminodiphenylsulfone (DDS) in nasal and nasopharyngeal rhinsporidiosis. Laryngoscope. 1979;89:291-5. $\underline{\text { Crossref }}$

4. Babu S, Anuradha A, Chandra S, Kashyap B. Nasal Rhinosporidiosis with Oropharyngeal extension. Ann Nigerian Med. 2011;5:24-7. Crossref

5. Arseculeratne SN. Microcystisaeruginosa as the causative organism of rhinosporidiosis. Mycopathologia. 2000;151:3-4. Crossref

6. Arseculeratne SN. Recent advances in rhinosporidiosis and rhinosporidiumseeberix. Indian J Med Microbiol. 2002;20:119-31. $\underline{\text { Crossref }}$ 